\title{
Public Health Intervention Framework for Reviving Economy Amid the COVID-19 Pandemic (1): A Concept
}

Jianqing $\mathrm{Wu}^{1}$, Ph.D., J.D. and Ping Zha ${ }^{2}$, M.D. (Chi. Med.)

April 8, 2020

(Work series paper, NOT published)

Correspondence: tempaddr2@atozpatent.com

1. End the Incurable Era (Independent researcher for cause), P. O. Box 689, Beltsville, MD 20704. www.igoosa.com.

2. Independent Researcher (Not affiliated with any entity), can be reached by using the above address.

Keywords: coronavirus, COVID-19, public health intervention, revive economy, disease severity, transmission route, influenza, ventilation, and work environment

\section{ABSTRACT}

The COVID-19 pandemic has great adverse impacts on personal life, the U.S. economy, and the world economy. Freezing all human activities is not a sustainable measure. Thus we want to develop a public intervention framework that allows people to resume personal and economic activities. In this article, we examined transmission routes, disease severity, personal vulnerability, available treatments, and person-person interactions to establish a general public intervention framework. We divide people into risk groups, non-risk group and group that may serve as viral transmitters, explore interactions between individual persons within each group and between different groups, and propose interaction behavior modifications to mitigate viral exposures. For the non-risk groups, we identified preventive measures that can help them avoid the most serious exposures and infections that pose higher death risks. The invention measures for the vulnerable groups include prior-exposure measures, heightened protective measures, interaction behavior changes, post-exposure remedial measures, and multiple factors treatments to reduce death and disability risks. The multiple interventions and two-ways defensive behavior modifications are expected to result in reduced rate of detectable infections and lowered disease severity for the vulnerable groups. In this framework, most human activities and economic activities can continue as normal. With time passing, the population acquires population immunity against the COVID-19 virus. Implementation of 
this intervention framework requires considerable resources and governmental effects while the multiple factors treatment protocol requires the support of health care professionals.

\section{INTRODUCTION}

At the time of writing this article, there are 1,464,852 confirmed cases, with 85,397 deaths in nearly 199 countries [1]. In the U.S., 417,206 infection cases with 14,183 deaths were reported in 54 states [2]. China used extraordinary measures to contain the outbreak at extreme cost to its economy. Many nations used similar approach in an attempt to contain local outbreaks.

The Wall Street firm lowered its first-quarter gross domestic product forecast to $-3.4 \%$ from $-2.4 \%$ and its second-quarter GDP forecast to $-38 \%$ from $30 \%$. On an annual average basis, Morgan Stanley expects real GDP contracting $5.5 \%$ in 2020, the steepest annual drop in growth since 1946. The Congressional Budget Office said on Thursday that the economy will contract by at least $28 \%$ in the second quarter [3]. Labor Department reported 701,000 jobs were lost in March. As economy struggles to recover from the initial recession, if the disease's impact dissipates, the U.S. economy may pick up to 3 percent or more by 2023 [4]. This optimistic projection is based on an assumption that no more pandemic strikes.

There is no predictable treatment for the disease in medicine at this time. The hope is finding effective drugs and vaccines, but it may take at least 12 month to 18 months for vaccine to reach the public [5]. There are many viruses that could strike at any time. Two other coronaviruses, OC43 and 229E, were discovered in the 1960s but had circulated in cows and bats, respectively, for centuries and other two, HKU1 and NL63, were discovered after the 2003-2004 SARS outbreak, also after circulating in animals [6]. Many of RNA viruses mutate rapidly [7] to generate new strains to defeat existing vaccine and drugs.

Breaking the chain of infection by identifying and controlling infected persons is impossible. Any diagnostic method produces a certain percent of false negative results, thus identifying all infected persons is impossible. Moreover, preliminary research from China suggests that the most common type of COVID19 test, known as a reverse transcriptase polymerase chain reaction (RT-PCR) test, may give false-negative results about $30 \%$ of the time [8].

(C) All right reserved, Wu \& Zha v100 2 
More than 43,000 people in China had tested positive without immediate symptoms by the end of February [9]. Those people may transmit the virus without even knowing it. Recently, the virus was transmitted in nursing home in Maryland. One local outbreak was reportedly caused by a health care worker who did not have a fever and was not screened out [10]. CDC recently stated that $25 \%$ infected persons have no symptoms.

It is obvious to see that the world cannot place its hope in medicine to contain the pandemic. Sound economic policies cannot be based on the strike of luck. The rapid increase in new cases in the U.S. and the world prompts us to examine existing measures that have been used in the fight against the pandemic and explore better intervention measures.

\section{DEVELOP A PUBLIC HEALTH INTERVENTION FRAMEWORK}

\section{A. Examine Death Risks for Different People in the Population}

We first note that medicine has complicated the disease by attempt to simplify it. Based on death data from China and the first 100 deaths in the U.S., it is clear that death risks are associated with certain vulnerable people.

Per CDC data [11], the first preliminary description of outcomes among patients with COVID-19 in the United States indicates that fatality was highest in persons aged $\geq 85$, ranging from $10 \%$ to $27 \%$, followed by $3 \%$ to $11 \%$ among persons aged $65-84$ years, $1 \%$ to $3 \%$ among persons aged $55-64$ years, $<1 \%$ among persons aged 20-54 years, and no fatalities among persons aged $\leq 19$ years. This pattern is similar to that seen in China, and the death rate among diagnosed cases is just under 1.4\% [12]. By using the population approach, this death rate is improperly applied to the population and thus creates panic.

If we consider the COVID-19 disease in personalized medicine, the disease severity as inferred from the population's death rate is irrelevant to young and healthy people. While "locking down" is the best measure to contain an outbreak when its target population or death risk is unknown, it cannot be used on a longterm basis.

\section{B. An Approach Based on the Binary Values Cannot End the Pandemic Due to Excessive Errors and Inaccuracies}

The limitations of demographic studies include accuracy of diagnosis or causes of death on death certificates, estimates of population, migration from areas of study, and the issue of "ecological fallacy" [13]. Demographic studies pay attention to the characteristics of population groups as a whole. Even though, population approach has been used in medicine as the golden standard for more than a century, we proved by rigid proof that health data cannot be summed and averaged to form model data for treating individual patients [14]. 
For the same reason, we assume that public health inventions based on population data is not effective because such data is inapplicable to individual persons unless the invention has very strong effect on all individual persons.

Epidemiological models such as deterministic compartmental model [15] use a presumption that infection takes two values: infection and no-infection. This presumption does not hold for most diseases and health properties. There is no rule that infection is caused by an identical infecting act which results in the same disease severity. Similarly, most interventions are quantitative in nature. Disease severity depends quantitatively on many parameters such as the number of viral particles, the locations of infection, host responses and immune responses. A more important factor is the relative speed between viral actions and immune responses [16]. Thus, most important factors for containing the pandemic are not reflected in the model. If all parameters are kept constant, the disease severity is down graded to a mild cold; and the whole pandemic just disappears. This simple and irrefutable logic supports our finding that population based research method has limited utility.

In epidemiological studies, exposure and disease occurrence are often rated in the binary values; and occurrence of an investigated effect is rated by frequency (occurrence also in binary values). Formation of this tradition could be traced to the common law practices which always turn quantitative properties into binary values. Conversion of a health property into two possible binary values is like digitizing a sound profile by a 2-bit scheme, which naturally introduces great errors and great inaccuracies. The great distortion of health properties is one of the reasons of poor treatment results. Moreover, it is difficult to investigate multiple factors at once in observational studies. The findings of epidemiological studies are useful in understanding disease nature and resource allocation, but cannot be used in treating diseases.

Existing epidemiological models are unable to address viral and host interactions that determine the effectiveness of public health interventions. Even if an infection has stricken a person, the disease severity depends on the speed contest between viral reproduction and immune response [16]. A small number of infections may be cleared by innate immunity and host responses; a certain number of initial infections may result in disease symptoms; more severe infections may cause more serious disease. Thus, the presumption of taking binary values is like a model focusing the unimportant part of the disease. Such model cannot focus on disease severity. Similarly, existing models treat interventions also in binary values, but not quantitatively. Six feet is applied to persons in all situations; but reality is that distance affects disease severity quantitatively.

The need for using the quantitative approach is that the virus cannot be treated in binary values. Getting rid of the virus is impossible. To extinguish a pandemic, a measure must be as extreme as lock-downing city, shutting down business, and quarantining all infected persons. All such extreme interventions still cannot make the virus disappear; and nothing can stop it from coming back.

(C) All right reserved, Wu \& Zha v100 4 
Local outbreaks can happen due to false negative test results, insufficient isolation times, asymptomatic infections, chronic virus carriers, animal virus carriers, failure of distance rule, etc. Such attempts cannot achieve the best outcome. Containing the pandemic would depend on weather and good luck. Existing research models are not useful in investigating disease progression speed.

In contrast, reducing disease severity of infected persons is much easier. We have shown with irrefutable evidence that disease severity can be altered by four classes of factors $[16,17]$. By using the quantitative approach, hundreds to thousands treatment factors can be used and their benefits are added up to make real difference in disease outcome of each infected person. However, the quantitative approach is in conflict with the binary approach.

The binary approach not only fails to contain the outbreak, but has precluded the quantitative approach from being used. Medical research model is also characterized by simplified model [14]. If a study is intended to study one factor a time, the study naturally rejects each weak intervention because it is not strong enough to change disease outcome on the binary scale. All weak interventions are not strong enough to reach the dividing point of two values. The false result is also due to the interference of many other factors [14]. Also, the errors introduced from converting into binary properties are larger than the true benefits so that the true benefits cannot be detected. Each of all weak interventions is thus rejected in turn, ending up with no cure.

We have extensively evaluated the disease severity from kinetic point of view [16, 17, 18, 19]. All of those studies are based on the quantitative approach. Based on that framework, we first evaluate advantages and weaknesses of the current interventions.

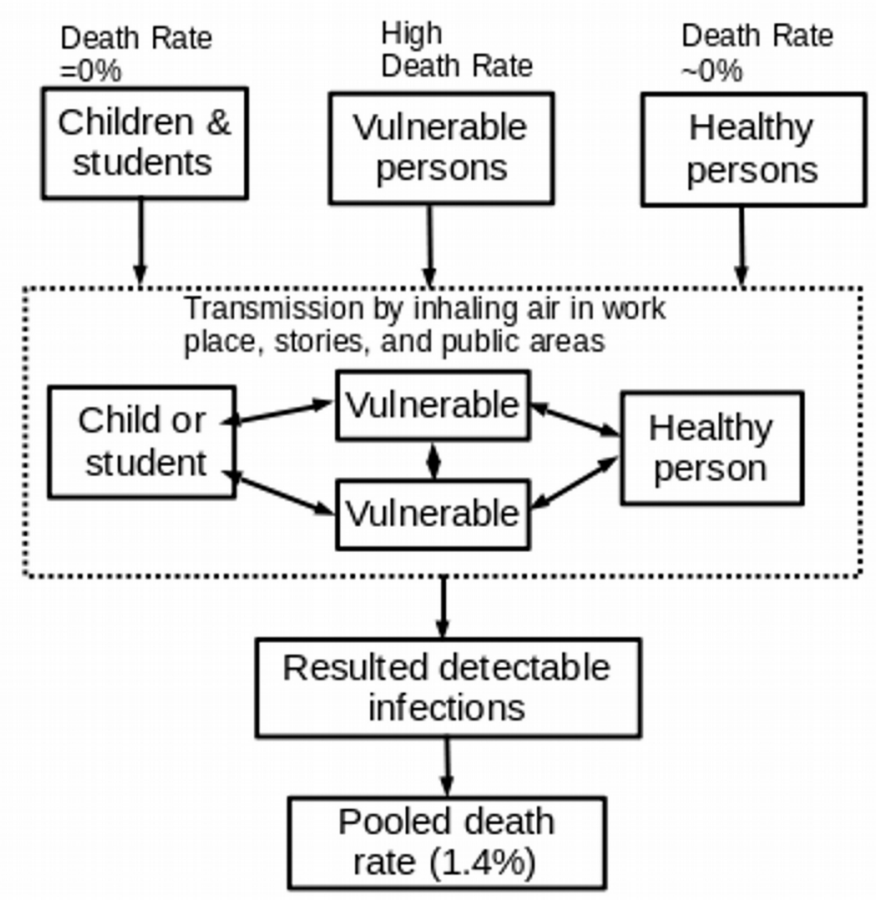

(C) All right reserved, wu \& $\angle$ ha viuu 
Figure 1. All persons in all groups can transmit the virus in all personal interactions in work sites, stories, and other public places. This results in a "population death rate" of $1.4 \%$. When a social distance measure is used and personal interactive activities are prohibited, the interventions have the effects shown in Figure 2.

When the social distance rule is followed, it reduces the risk of viral transmission from infected persons to uninfected persons, as shown in Insert (a). However, the measure cannot protect the person from viral particles that have been suspected in the air or that are from people who have been in the building. Since most people still appear in some public places such as stories, restaurants, and offices without using protection such as masks. At job sites, the virus can transmit from an infected employee to other employees. When those employees visit stories or other public places, they shed the virus and contaminate the air; and the virus then infects some occupants in the public places. Sharing air in both work sites and public places forms complete transmission chains. Any person from any company may transmit the virus to anyone from other companies. When a large number of people are infected, they also visit other public places such as stories, hospitals, trains, etc. within the inoculation times, and thus transmit the virus to others who happen to be there. Thus, anyone in one family can transmit the virus to anyone in other families in any part of locality or city. The social distance intervention is clearly insufficient. The transmission chains cannot be established later to track potentially infected persons.

The outcome of the population, which is often expressed by statistical data, comprises disease outcomes of infected persons. None of personal disease outcomes is really run by statistical law like flipping a coin. Public health interventions can alter the disease outcome of the population by influencing individual persons. When the interventions are applied to persons, the prediction of a traditional epidemiological model will be defeated. Therefore, the strategy is to mitigate disease severity for individual persons. 
(a) Social Distance and Lockdowns (most effective)

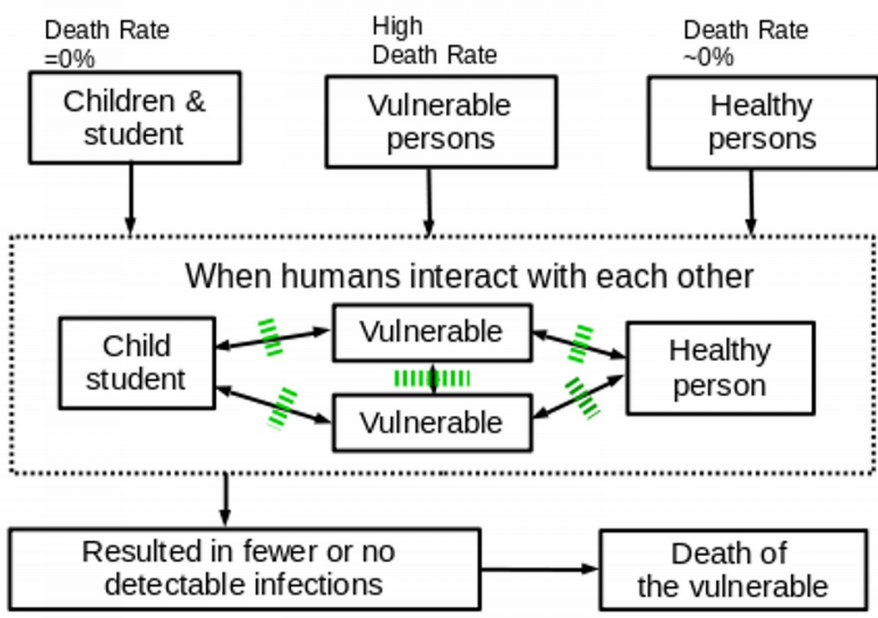

(b) Transmission In Closed Public Places (stores, offices, etc.)

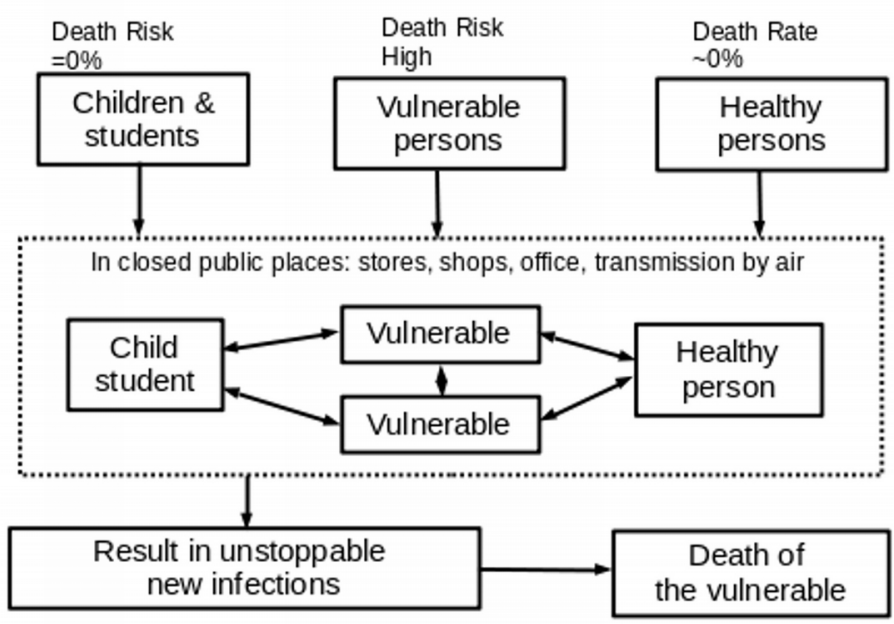

Figure 2. Social distance and lock-down can completely break the chain of transmission as shown in Insert a. However, people can transmit the virus through shared air in closed or poorly ventilated public places such as stories, offices, restaurants, classrooms, trains, buses, ships, airplanes, etc.

Lock-down is an effective measure if it can completely bar all personal contacts and interactions. If persons must contact others briefly, additional measures must be taken to prevent the virus from transmitting through air. To stop transmission in brief contacts, all persons must wear masks to block the transmission shown in Insert b. Lock-down can be defeated if viral transmission is not stopped during brief personal contacts in closed public places.

\section{A Concept Public Health Invention Framework}


We note that the disease causes only about $1.4 \%$ death rate among all infected persons. However, focused interventions can be directed to the small number of vulnerable people. High death rates are identified for the vulnerable people. Thus, mitigation measures are directed to vulnerable persons. Third, we also found that the disease severity depends on a large number of factors, and a large number of measures can be used to mitigate disease severity in a long time window from before the infection to post recoveries. The reasons for using those measures was discussed in our articles $[16,17]$. The measures are shown in Figure 3.

In this concept intervention framework, we classify all people into three main classes: those who attend schools and universities, those who are healthy and working, and those who are vulnerable to the virus. The children and students continue attending their schools; and healthy persons, with limited exceptions, do their regular things, engage normal social activities, and do their regular jobs. However, the vulnerable people are protected by five lines of intervention measures: prior-exposure measures, heightened protective measures, personal interaction manner modifications, post-exposure remedial measures, and multiple factor treatments for infected persons.

\section{A Intervention Framework for Reviving Economic Activities}

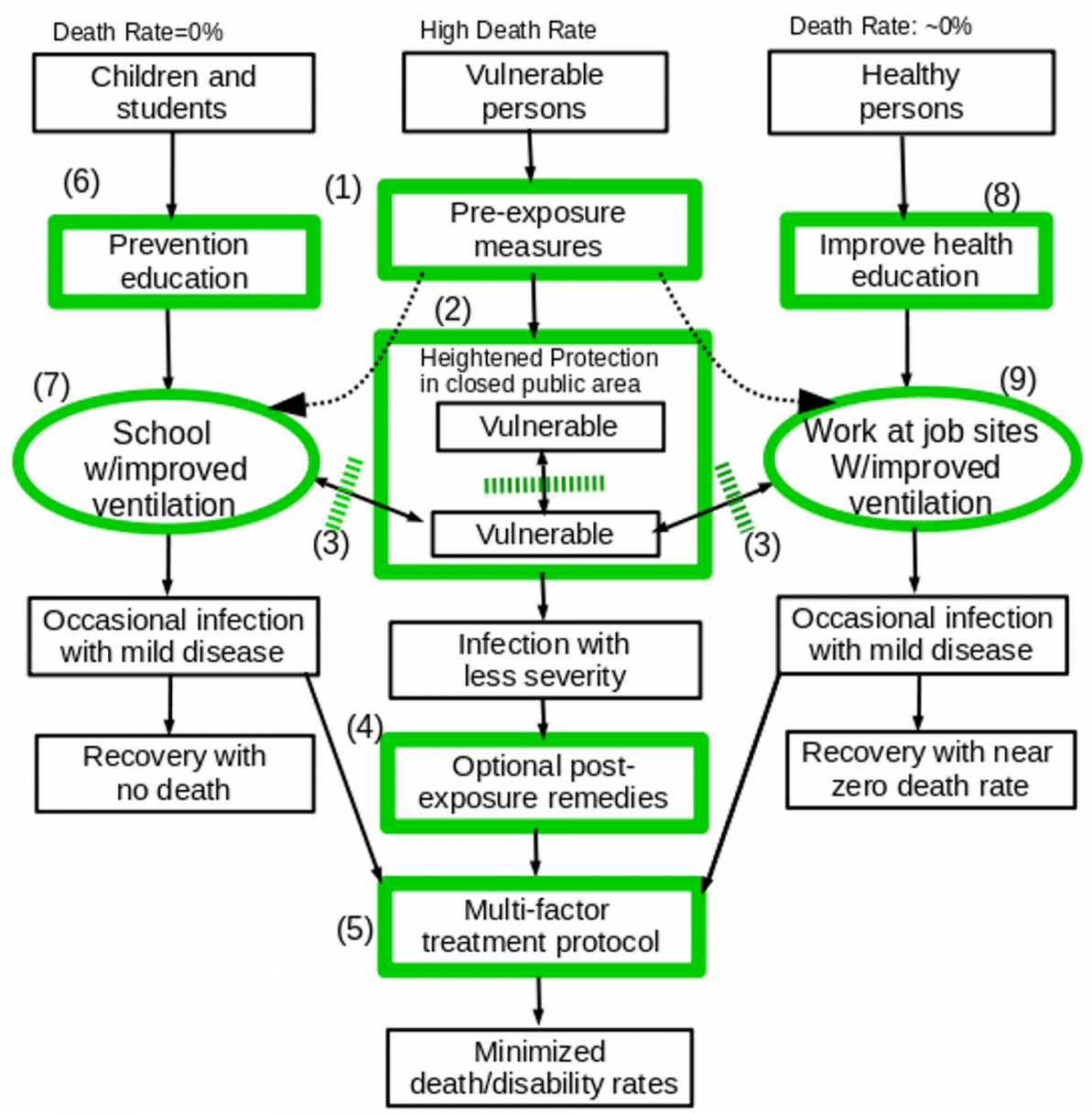


Figure 3 shows all public health intervention points (1-9) by green lines. The focus is not breaking chain of infection, but reducing disease severity, particularly, the death rate and disability rate for the vulnerable group. It is not necessary to use measures at all invention points. The prior-exposure measures are taken to improve personal resistance to the virus, and may include anything that can inhibit viral replication, boost antiviral immunity, improve lung microcirculation, and improve organ functions. Heightened protective measures include everything that protects the vulnerable persons in all kinds of scenarios. This line of measures may change working settings, improve ventilation, and using protective devices such as mask in daily activities. The third line measures are defensive personal interaction manners, which are exercised by both interactive persons. Those measures are employed to reduce disease severity with limited impacts on infection rate.

If vulnerable persons get the disease, they are treated by using multiple factor health optimization method. Drugs may be used as important component, but a large number of other factors are used to slow down viral reproduction, speed up immune response, and improve lung-waste removal efficiency. The measures are used collectively to reduce the area between the viral reproduction curve and the immune response curve, and the draining of inflammation products, metabolic by-products, and wastes from immune responses.

All vulnerable persons may be encouraged to take post-exposure remedial measures if they realize that have been exposed to the virus in significant levels. The measures are taken promptly after suspected exposures. Remedial measures may include washing off nasal cavities using non-irritable salty water, altering physiological body conditions, or any newly found methods for cleaning or inactivating remaining viral particles on the respiratory track.

For children and students, the main intervention measures are education to improve their understanding of preventive measures and person-person interaction manners. In a long-term plan, school ventilation systems should be systematically upgraded so that they are capable of reducing viral concentrations to background levels when a significant number of students are shedding the virus.

For healthy persons, intervention measures include doing necessary exercises to improve holistic health and increasing organ functional capacity, and learning preventive knowledge. The main education point is avoiding worst lung exposure that would result in widespread lung infection and big mistakes in fighting an infection. Another measure is to improve ventilation systems so that the systems can filter out most virus-containing particles from the air.

The intervention framework is only a concept. Each of the interventions at each point should be used to achieve as best protection as possible as a general rule. The effectiveness of each intervention is determined in a quantitative basis. 
Every health or disease property in nature is from zero to a maximum value. The property is not rated by a threshold point as a dividing point for two values. The quantitative approach is reducing errors that can defeat the effort of interventions. The 6 feet social distance may be insufficient in some cases; the 14-day isolation time may be too short for some persons; viral tests may fail to capture infected persons; active patients may be discharged on false negative results; patients may experience relapsed infections; infected persons may have no symptoms; people may get repeated infection due to immune compromise, etc. There are many reasons for failure to break the chain of infection. For all those reasons, the binary approach is replaced by the quantitative approach.

Using the quantitative approach can avoid errors that could be introduced from using the binary scale. However, the three classes in Figure 3 are similar to a binary scale. When people are classified only in three classes, very different people are treated in the same way as in the case of using the population approach. The central blocks could be drawn as several lanes, each of which is for a sub class of vulnerable people. The sub classes may include one for people with lung problems, one with kidney problems, and one with immune system problems, etc. Moreover, a healthy person may choose to follow the intervention measures for the vulnerable to achieve highest safety margins. Specific interventions are tailored to each sub class. For those with suppressed immune systems, the preventive measures at point 1 may be used to get rid of heavy metals that cause it; but for those with heart problems, the measures are to remove stored fats, improve micro circulation, etc. The measures in any point are different, depending on specific persons and circumstance. If an infected person is a super-viral spreader, the distance for social distance in point 2 should be longer.

Figure 3 can be reduced to a binary intervention framework if the COVID19 pandemic loses its threat to human life or effective treatments are found. In this case, effective interventions do not require high accuracy.

People are taught to exercise due care in interacting with people who have been released from quarantines or on negative viral test results. The goal is reducing viral amounts in all viral exposures. The lowest viral amount is associated with the lightest disease severity. When better intervention measures are used, disease risk moves on the continuous scale toward the side with the lowest disease severity, and thus results in reduced disease severity. While a better intervention is trivial when it is viewed on a single case, it can have a large impact on a population when it is used by all persons: fewer persons get infected; fewer persons get severe diseases; more persons do not experience disease symptoms; and survivals have less lung damages.

The level of due care in human interactions should vary, depending on persons and circumstances. The required effectiveness degree of each measure is commensurate with personal vulnerability, expected transmission risks, environmental factors, and threats to others. Each intervention point depends on outbreak or seasons. In an outbreak season, high duty of care should be 
exercised by both persons when they interact with each other. While six feet distance may be used as a default distance for convenience, it could be 5 meters if one person or both persons are more vulnerable, one person is ill, environment is unfavorable, or one of the persons is under emotional distress. In a nonoutbreak season, the level of duty of care in an interaction between a child and a healthy adult is the minimum. In contrast, both sides should exercise higher duty of care in an outbreak season. For doctors who routinely contact people, protective measures should be taken with the highest duty of care.

The outcome of a population is the sum of outcomes of individual persons. Improved interventions on personal levels are expected to alter the disease outcomes of the population. Population death rate depends on medical treatments effectiveness. If intervention measures lower death risk or disability risk on each person by a certain amount, the measures could roughly reduce the population's death rate or disability rate by similar amounts on a relative scale. Notwithstanding the nonlinear and complex relationship between disease severity and interventions, we expect that the beneficial impact of interventions could be enough to substantially reduce population's death rate.

In dealing with the pandemic, due to influences of population approach, the performance is often judged by population data. However, effective treatments must be based on individual persons in personalized medicine [14, 16, 17]. Any population-based measure is poor or unworkable. A health care worker who would infect a large number of people under the binary interventions may reduce infected persons to a smaller number as a result of using preventive interventions quantitatively. The measure may help the worker reduce the amount of shed virus by a certain amount. This necessarily results in less severer outbreak from this worker. Further better outcomes for infected persons may be achieved by using preventive, remedial, treatment and recovery measures, resulting in a higher survival rate. When personal data are pooled together to generate population data, the interventions actually achieve better performance.

If the intervention framework is implemented well, it should have same effect as the lock-down measures because every transmission routes are blocked. However, this framework will not show immediate benefits if a large number of infected persons are in inoculation periods. They show up their symptoms before the framework starts working.

\section{Analysis of Well known Public Health Interventions}

Some public health interventions are shown in the following table. We also include measures that have not been used in the U.S. and many Western nations.

Table 1. Performance of Public Health Interventions, their Weaknesses and Reasons of Failure.

\begin{tabular}{|l|l|l|l|l|}
\hline $\begin{array}{l}\text { Intervention } \\
\mathrm{s}\end{array}$ & Effectiveness & Evidence & $\begin{array}{l}\text { Reasons of } \\
\text { Potential Failure }\end{array}$ & Comments \\
\hline
\end{tabular}




\begin{tabular}{|c|c|c|c|c|}
\hline $\begin{array}{l}\text { 1. Lock- } \\
\text { down }\end{array}$ & $\begin{array}{l}\text { Highly } \\
\text { effective }\end{array}$ & $\begin{array}{l}\text { China } \\
\text { COVID-19 }\end{array}$ & $\begin{array}{l}\text { If people live in a } \\
\text { crowd city }\end{array}$ & $\begin{array}{l}\text { Extreme cost, and } \\
\text { cripple economy }\end{array}$ \\
\hline $\begin{array}{l}\text { 2. Improved } \\
\text { ventilation/ } \\
\text { electrostati } \\
\text { c particle } \\
\text { collector }\end{array}$ & $\begin{array}{l}\text { Most } \\
\text { effective in } \\
\text { working } \\
\text { place, and } \\
\text { closed public } \\
\text { place }\end{array}$ & $\begin{array}{l}\text { Viral particle } \\
\text { in air is the } \\
\text { most lethal } \\
\text { transmission } \\
\text { route }\end{array}$ & $\begin{array}{l}\text { Poor system with } \\
\text { insufficient ability } \\
\text { to filter out viral } \\
\text { particles }\end{array}$ & $\begin{array}{l}\text { Expensive for } \\
\text { remodeling the } \\
\text { systems }\end{array}$ \\
\hline $\begin{array}{l}\text { 3. Wear } \\
\text { mask }\end{array}$ & $\begin{array}{l}\text { Being very } \\
\text { effective to } \\
\text { reduce } \\
\text { disease } \\
\text { severity }\end{array}$ & $\begin{array}{l}\text { Indirect } \\
\text { evidence: } \\
\text { reduce } 80 \% \\
\text { to } 99 \% \text { of } \\
\text { viral particles }\end{array}$ & $\begin{array}{l}\text { If a person is in a } \\
\text { viral environment } \\
\text { too long, the viral } \\
\text { load is added up } \\
\text { to make } \\
\text { infections worse }\end{array}$ & $\begin{array}{l}\text { For an infected } \\
\text { person, mask can } \\
\text { cause severer } \\
\text { lung infections }\end{array}$ \\
\hline $\begin{array}{l}\text { 4. Social } \\
\text { distance }\end{array}$ & $\begin{array}{l}\text { Effective to } \\
\text { stop } \\
\text { transmission } \\
\text { by coughed } \\
\text { droplets and } \\
\text { large } \\
\text { particles }\end{array}$ & $\begin{array}{l}\text { Large } \\
\text { droplets fall } \\
\text { into the } \\
\text { ground } \\
\text { quickly. }\end{array}$ & $\begin{array}{l}\text { It may be } \\
\text { ineffective in } \\
\text { some cases; and } \\
\text { ineffective to } \\
\text { small particles in } \\
\text { air }\end{array}$ & $\begin{array}{l}\text { Disease severity } \\
\text { depends on } \\
\text { health, infection, } \\
\text { other factors, etc. } \\
\text { Six feet is not a } \\
\text { magic number. }\end{array}$ \\
\hline $\begin{array}{l}\text { 5. Use of } \\
\text { groves }\end{array}$ & (Unknown) & $\begin{array}{l}\text { Prevent virus } \\
\text { from entering } \\
\text { skin or soft } \\
\text { tissue }\end{array}$ & & $\begin{array}{l}\text { It causes a huge } \\
\text { amount of } \\
\text { environmental } \\
\text { wastes }\end{array}$ \\
\hline $\begin{array}{l}\text { 6. 14-day } \\
\text { observation } \\
\text { time }\end{array}$ & Limited & $\begin{array}{l}\text { Most people } \\
\text { have less } \\
\text { than } 14 \text { days } \\
\text { incubation } \\
\text { time }\end{array}$ & $\begin{array}{l}\text { Incubation time } \\
\text { for some persons } \\
\text { are longer }\end{array}$ & $\begin{array}{l}\text { Incubation time is } \\
\text { a complex } \\
\text { function; and } \\
\text { infection after } 14 \\
\text { days revive an } \\
\text { outbreak }\end{array}$ \\
\hline $\begin{array}{l}\text { 7. Viral } \\
\text { tests }\end{array}$ & Limited & $\begin{array}{l}\text { Test data } \\
\text { showing } \\
\text { correct test } \\
\text { result }\end{array}$ & $\begin{array}{l}\text { False negative } \\
\text { results due to } \\
\text { incubation time, } \\
\text { test skills, and } \\
\text { problem in test } \\
\text { kits }\end{array}$ & $\begin{array}{l}5 \%-30 \% \text { false } \\
\text { negative rate can } \\
\text { revive an } \\
\text { extinguished } \\
\text { outbreak }\end{array}$ \\
\hline $\begin{array}{l}8 . \\
\text { Protective } \\
\text { uniforms, } \\
\text { goggles, } \\
\text { etc. }\end{array}$ & $\begin{array}{l}\text { Questionable, } \\
\text { but may help } \\
\text { in heath care } \\
\text { setting }\end{array}$ & \begin{tabular}{|l} 
Uniforms \\
shield viral \\
particles
\end{tabular} & $\begin{array}{l}\text { (Other } \\
\text { transmission } \\
\text { route is more } \\
\text { important) }\end{array}$ & $\begin{array}{l}\text { Social resources } \\
\text { for making them } \\
\text { and of cleaning } \\
\text { them. }\end{array}$ \\
\hline
\end{tabular}




\begin{tabular}{|c|c|c|c|c|}
\hline $\begin{array}{l}\text { 9. Using } \\
\text { disinfectant }\end{array}$ & $\begin{array}{l}\text { Presumed to } \\
\text { be good, but } \\
\text { over-doing is } \\
\text { a problem }\end{array}$ & $\begin{array}{l}\text { Based on } \\
\text { evidence it } \\
\text { can } \\
\text { inactivate } \\
\text { virus }\end{array}$ & $\begin{array}{l}\text { (Skin is not a } \\
\text { lethal } \\
\text { transmission } \\
\text { route) }\end{array}$ & $\begin{array}{l}\text { It can strain } \\
\text { resources if it is } \\
\text { used too often }\end{array}$ \\
\hline \begin{tabular}{|l}
10. \\
Personal \\
isolation
\end{tabular} & $\begin{array}{l}\text { Effective, but } \\
\text { pose some } \\
\text { risk to family } \\
\text { members }\end{array}$ & $\begin{array}{l}\text { Break chain } \\
\text { of contact }\end{array}$ & $\begin{array}{l}\text { Transmission } \\
\text { through family } \\
\text { members }\end{array}$ & $\begin{array}{l}\text { Much better than } \\
\text { quarantine }\end{array}$ \\
\hline $\begin{array}{l}11 . \\
\text { Quarantine }\end{array}$ & $\begin{array}{l}\text { Effective for } \\
\text { protecting } \\
\text { the pubic, } \\
\text { but bad for } \\
\text { infected } \\
\text { persons }\end{array}$ & $\begin{array}{l}\text { Break chain } \\
\text { of infection }\end{array}$ & $\begin{array}{l}\text { Cross-infection, } \\
\text { successive } \\
\text { infections, } \\
\text { emotional } \\
\text { distress, and } \\
\text { using masks }\end{array}$ & $\begin{array}{l}\text { Need to design } \\
\text { air ventilation } \\
\text { systems to avoid } \\
\text { additional } \\
\text { infections }\end{array}$ \\
\hline $\begin{array}{l}12 \text { Anti viral } \\
\text { drugs }\end{array}$ & $\begin{array}{l}\text { Can be } \\
\text { effective if it } \\
\text { is used early }\end{array}$ & $\begin{array}{l}\text { Based on } \\
\text { population } \\
\text { trial }\end{array}$ & $\begin{array}{l}\text { Some people do } \\
\text { not respond }\end{array}$ & $\begin{array}{l}\text { Side effect on } \\
\text { some persons. No } \\
\text { good drug now }\end{array}$ \\
\hline $\begin{array}{l}\text { 13. Other } \\
\text { drugs }\end{array}$ & Depend & $\begin{array}{l}\text { Based on } \\
\text { population } \\
\text { trials }\end{array}$ & $\begin{array}{l}\text { Some people do } \\
\text { not respond }\end{array}$ & $\begin{array}{l}\text { None at the } \\
\text { present time }\end{array}$ \\
\hline $\begin{array}{l}14 . \text { Prior } \\
\text { exposure } \\
\text { measures }\end{array}$ & $\begin{array}{l}\text { Depend, but } \\
\text { work slowly, } \\
\text { but could } \\
\text { make } \\
\text { difference }\end{array}$ & $\begin{array}{l}\text { Based on } \\
\text { medical } \\
\text { study } \\
\text { findings }\end{array}$ & $\begin{array}{l}\text { Do not depend } \\
\text { molecular } \\
\text { specificity }\end{array}$ & $\begin{array}{l}\text { Lack a culture of } \\
\text { using it; and } \\
\text { takes time to see } \\
\text { benefits }\end{array}$ \\
\hline $\begin{array}{l}\text { 15. Post } \\
\text { exposure } \\
\text { remedies }\end{array}$ & $\begin{array}{l}\text { Limited } \\
\text { options, and } \\
\text { more may } \\
\text { come in } \\
\text { future }\end{array}$ & $\begin{array}{l}\text { Based on } \\
\text { viral action } \\
\text { times, latent } \\
\text { time or } \\
\text { inoculation } \\
\text { time }\end{array}$ & $\begin{array}{l}\text { Corrective } \\
\text { remedies are too } \\
\text { later, they have } \\
\text { less benefits }\end{array}$ & $\begin{array}{l}\text { Most people do } \\
\text { no believe them }\end{array}$ \\
\hline $\begin{array}{l}16 . \text { Multi- } \\
\text { factor- } \\
\text { treatment }\end{array}$ & $\begin{array}{l}\text { Can be highly } \\
\text { effective, but } \\
\text { require } \\
\text { knowledge to } \\
\text { use it }\end{array}$ & $\begin{array}{l}\text { Based on } \\
\text { medical } \\
\text { study } \\
\text { findings }\end{array}$ & $\begin{array}{l}\text { Lack of interest; } \\
\text { wrong treatment } \\
\text { factors, etc. }\end{array}$ & $\begin{array}{l}\text { Lack a culture of } \\
\text { using it; and take } \\
\text { time to see } \\
\text { benefits }\end{array}$ \\
\hline
\end{tabular}

Each of the interventions based on the binary scale can cause problems in various situations. When those measures are used rigidly, they are either excessive or insufficient, depending on persons and other factors. If people rely on fixed rules rigidly, they can revive an extinguished pandemic. Mask may be worn to ruin the lungs in infected persons; six feet distance may fail to protect 
certain persons; groves and protective uniforms may be wasted if the lungs are wildly open to airborne virus; the 14 days incubation time may be too short; a negative test results may be incorrect. Each instance caused by any of those errors can cause local outbreaks. Due to long incubation times and lack of symptoms, the virus can be transmitted to others before the infected person even knows his infection. Thus, breaking chain of infection is impossible.

A vast number of those problems can be resolved by the quantitative approach. It is not premised on the notion to extinguish the virus and any error will not defeat the performance of such interventions. Moreover, since interventions are used to achieve a best result, an error can only nullify some safety margin built in the framework. Such errors cannot completely defeat the interventions as in case of a binary approach. The goal is not to prevent all infections or extinguish the virus, but to reduce disease severity by using multiple layers of protective measures. If the first layer of measures fails, the second, third, fourth layers will work, all being intended to reduce disease severity. The final goal for the population is accepting the virus as a common illness, and build population immunity against the virus.

\section{E. Disease Severity Is Continuous Properties Controlled by Viral Load and Many Other Factors}

The merit of the proposed intervention framework lies in use of the quantitative approach. The poor performance of existing interventions is clearly caused by the use of the binary approach. The COVID-19 disease and all health properties are quantitative properties that can be best modeled by quantitative models. Disease severity may be defined by death rate, disability rate, and other suitable properties such as days of recovery, temporary organ function loss, costs of essential treatments, etc. The most important parameters are death rate and disability rate. Even though death is a binary property in most cases, all known causes that cause death are continuous properties. The causes of death in COVID-19 are lung damages or lost lung function, reduced oxygen saturation degree, impaired heart function, impaired renal functions, etc. Regardless of the final cause of death, viral reproduction speeds are always determinant factors. Since lungs are the primary target organs, the total number of damaged cells and severity of damages of lung cells must be the most important factors. Thus, disease severity depends on the number of infection points where the virus makes entry and viral reproduction speeds at each infected site. None of those factors is a binary property.

We show that seed infection points, subsequent successive infection points, and viral reproduction speeds at each point are all continuous properties. Classical infection theories imply that, as the viral concentration increases, the percentage of cells infected with at least one viral particle increases [20]. When more cells are infected, the virus obviously causes severer damages. Under the well accepted viral collective infection theory [21, 22, 23, 24, 25], viral spread is often facilitated by groups of virus forming complex infectious structures. The 
required virus-virus interactions within a small viral molecular interaction distance imply that infection requires certain viral concentrations and may require a minimum time to form infectious structures. None of them is a binary property.

Human lungs normally have about 600 million alveoli (although the number may differ). Each alveolus may be made of 40 type I cells and 77 type II cells [26]. So, the lungs have about 70 billion cells that are exposed to the internal air way by well structured airway channels. When the statistical process applied to the lungs, it is inevitable to reach the conclusion that the virus can make entries in any part of lungs at similar or varying probabilities. Moreover, the virus may attack each of the cells even though host responses triggered by infected cells might affect the chance of infecting neighbor cells.

The virus particles number is accumulated by time. Based on influenza study, normal (tidal) breathing can shed viral particles by the exhaled air [27]. Exhaled influenza virus RNA generation rates range from 3.2 to 20 influenza virus RNA particles per minute and over $87 \%$ of particles exhaled were under 1 $\mu \mathrm{m}$ in diameter. In a closed small room, the viral concentration could rapidly rise (add about 28,800 RNA copies/day for influenza virus, even though some of them fall on ground slowly). Influenza virus could be detected in the exhalations of infected persons during normal tidal breathing or talking but not during coughing [28]. Other studies showed that respiratory particles by influenza patients were produced while breathing or coughing, but not both maneuvers side-by-side [29, 30, 31]. The conflicts among different studies implies that the exact number of viral particles that an infected person can produce depend on many factors. In air samples collected from a school during an influenza season, influenza A virus was detected in densities ranging from $2.0 \times 10(-1)$ to $1.9 \times 10(4)$ (gene copies m-3 air) [32]. Detected viral concentrations, particle sizes and traveling distances are quantitative properties [33, 34, 35, 36, 37].

The degree of damages to the lungs depends on the total viral load and the ability of the immune system. Immunocompromise, underlying health condition, and drugs affect influenza viral reproduction and viral shedding [38, 39, 40, 41, $42,43]$. We assume that the body can clear up viral infection by a small number of viral particles, but cannot stop the virus if the viral number is too large. The ability to contain the highest viral concentration would depend on the body health condition and must vary from person to person. A universal binary dividing point does not exist for all persons.

Alveolar macrophages are important in lung inflammation and resolution $[44,45]$. Human lungs have about 20 million resident macrophages for potentially 600 million alveoli. There is only one macrophage for about every 30 alveoli. This ratio may vary due to differences in persons. A low macrophages/alvoeli ratio is also seen in mouse: one macrophage is present for every three alveoli [46]. 
Virus must exist in the form of foreign particles which might comprise viral RNA molecules, water molecules, dissolved gases, and biological materials. Based the look of discharges, one could infer that the substances in airborne particles must vary greatly, depending on infected persons and health conditions. How alveolar macrophages carry out its function against inhaled pathogens is not entirely clear. According to one possibility, resident macrophages continually patrol the alveolar surface; and evidence even indicates that alveolar macrophages could serve as antigen carriers transporting pathogens to lung draining lymph nodes [45]. Although the findings support the notion that under pathogen challenge, some alveolar macrophages might migrate to lymph nodes, there is no direct evidence that macrophages can move and patrol alveoli. In fact live optical studies suggest that fixed alveolar macrophages do not migrate from their home alveoli despite the presence of bacteria in adjoining macrophage-free alveoli [44]. It was found that monocytes participate in steady-state surveillance of the lungs in a way that is complementary to resident macrophages and dendritic cells without differentiating into macrophages [47].

It is unnecessary to resolve the question on the mobility of macrophages and potential role of monocytes, one inevitable conclusion is that the ability of the lungs to remove foreign objects such as airborne particles is limited. If a small number of viral particles get into the lungs, they may be cleaned up by macrophages, dendritic cells, and monocytes. The lungs are unable to remove a large number of inhaled foreign objects. The failure points vary widely from person to person. There is no universal point that can be applicable to all people in a population. The inevitable conclusion is some healthy persons can tolerate a lot more viral particles than those with poor immune systems.

The respiratory air flow structure and non-stopping breathing cycles greatly favor viral spread within the lungs [19]. If the host responses and innate response fail to get the virus, some viruses make entries into the lung or other cells. The viral reproduction activities trigger the acquired immune response. Thus disease severity depends on relative speeds between the viral reproduction process and the immune response [16, 17]. Lungs are further damaged by a reinfection process $[17,18,19]$. As implied by both probability theory and collective infection theory, all uninfected cells can be infected by virus generated from the patient. Moreover, both viral number and mutants can increase viral virulence. Thus, the ability of the lungs to prevent viral initial entries and ability to clear up infections varies greatly, depending on a large number of factors.

None of the above problems can be properly addressed by randomized controlled trials. There is no fixed dividing point that is good for every person in a population. If a critical health property is divided into two values based on population data, the dividing point introduces two kinds of errors for individual persons. It is too high for some persons but too lower for others. For similar reason, an intervention may be insufficient for some persons, but may be excessive for others. This is why a population-based treatment is not effective in treating personal diseases. 


\section{F. Risks of Failure of the Intervention Framework}

The real risk is that people in common law nations have a hard time to accept the quantitative approach. The convention of converting from every continuous property to a binary property can be traced to common law practices. In the early common law courts, everything was converted to a binary value: good person and bad person, criminal and non-criminal, consideration and lack of it, etc. In law, there are no gray areas besides two values. In medicine, very few health properties are binary, but most health properties are converted into two values (e.g., health and unhealthy). However, most properties addressed in experiments are continuous and so research operations have to treat data quantitatively. To comply with common law convention, experimental data are then converted back to conclusions which have to have two values. Most of properties such as blood pressure, health condition, etc. are converted into two values according to man-made dividing points. The conversion step introduces great amount of errors. Pooling and averaging population data do not cause problems if study findings are used as evidence for establishing policies, laws, and resource allocations, etc. However, such findings cannot be used as the basis for treatment protocols for individual persons.

Scholars from non-common law nations can readily see this problem. This intervention framework can be easily implemented in East nations. Anyone should be able to see problems from adding data from young men and old men, or from men and women to get data for some kind of averaged "human beings" that simply do not exist in nature. The framework cannot be easily implemented for a population that is used to treat things in binary values. Due to tradition influence, all interventions such as use of mask, social distance, incubation periods, etc. are treated as binary properties in all CDC publications [48, 49, 50]. After the CDC changed its default rule on mask use, we immediately saw people wearing masks while they are running and riding bicycles in widely open areas. Implementation of this framework would require great effect of education before people can accept the quantitative approach.

\section{LIMITATION OF THIS STUDY}

The validity of the proposed public health intervention framework depends on detailed measures and acceptance of the quantitative approach by the population. When effective drugs and vaccines are available, there may be diminished need to use intervention measures at all intervention points. If the virus mutates to alter disease severity on different groups of people, this may require adjustments to the current classification of vulnerable people. If a valid treatment is found, the treatment can be used as a treatment within this intervention framework. This concept intervention framework requires detailed measures, which can comprise a large number of options known now or 
discovered in the future. The performance of this framework naturally depends on the effectiveness of specific intervention measures which are tailored to personal, business, and economic activities.

\section{FUNDING STATEMENT}

The author(s) declared that no grant was used in support of this research project.

\section{CONFLICT OF INTERESTS}

None

\section{ADDITIONAL INFORMATION}

Additional information is provided in a supplemental document and some information will be stored in igoosa.com online database. This article may be used by any person for personal use as fair use; any use for research and development and public welfare is permitted by default.

\section{REFERENCES}

1. WHO, Coronavirus disease 2019 (COVID-19) Situation Report - 78 Data as reported by national authorities by 10:00 CET 7 April 2020. Accessed at https://www.who.int/emergencies/diseases/novel-coronavirus-2019/situationreports

2. Coronavirus Cases: United States, Last updated: April 07, 2020, 20:31 GMT. Accessed at https://www.worldometers.info/coronavirus/country/us/

3. Goldstein S. Morgan Stanley releases new forecast showing U.S. economy may drop as much as 38\%. April 3, 2020. Accessed at https://www.marketwatch.com/story/morgan-stanley-releases-new-forecastshowing-us-economy-may-drop-as-much-as-38-2020-04-03

4. Associated Press, Thu 2 Apr 2020. Coronavirus outbreaks like 'wildfire' at US nursing homes under lockdowns. Measures including a ban on visits and daily health screenings of staffers either came too late or were not rigorous 
enough. Accessed at https://www.google.com/search? channel=cus $2 \&$ client=firefox-b-1-d\&q=maryland+oldly+care+covid-19.

5. Thompson Dennis, Why Will It Take So Long for a COVID-19 Vaccine? April 6, 2020, HealthDay News. Accessed at https://www.usnews.com/news/health-news/articles/2020-04-06/why-will-it-takeso-long-for-a-covid-19-vaccine.

6. Abdul-Rasool S, Fielding BC. Understanding Human Coronavirus HcoVNL63. Open Virol J. 2010; 4: 76-84.

7. Domingo E., Holland J. J. (1997) RNA Virus Mutations and Fitness for Survival, Annual Review of Microbiology, 51: 151-78.

8. Yang Y., Yang M., Shen C. et al. Evaluating the accuracy of different respiratory specimens in the laboratory diagnosis and monitoring the viral shedding of 2019-nCoV infections. medRxiv preprint doi: https://doi.org/10.1101/2020.02.11.20021493.

9. Ma J, Lew L. and Jeong-ho L. A third of coronavirus cases may be 'silent carriers', classified Chinese data suggests. 22 Mar, 2020. South China Morning Post. Accessed at https://www.scmp.com/news/china/society/article/3076323/third-coronaviruscases-may-be-silent-carriers-classified.

10. Hein A. Maryland nursing home coronavirus outbreak may have started with asymptomatic staffer, gov says. Fox News. April 2, 2020. Accessed at https://www.foxnews.com/health/maryland-nursing-home-coronavirus-outbreakstarted-asymptomatic-staffer-gov-says

11. CDC, Severe Outcomes Among Patients with Coronavirus Disease 2019 (COVID-19) - United States, February 12-March 16, 2020. The report was posted online on March 18, 2020 as an MMWR Early Release. Weekly/March 26, 2020/69(12);343-346.

12. Verity R, Okell LC, Dorigatti I et al. Estimates of the severity of coronavirus disease 2019: a model-based analysis. Lancet Infect Dis 2020. Published Online March 30, 2020. https://doi.org/10.1016/Published online March 30, 2020 https://doi.org/10.1016/S1473-3099(20)30243-7.

13. Lilienfeld AM. Practical Limitations of Epidemiologic Methods. Environmental Health Perspectives. Vol. 52, pp. 3-8, 1983.

14. Wu, JQ and Zha, P. Randomized Clinical Trial Is Biased and Invalid In Studying Chronic Diseases, Compared with Multiple Factors Optimization Trial (November 4, 2019). Available at SSRN: https://ssrn.com/abstract=3480523 or http://dx.doi.org/10.2139/ssrn.3480523 
15. Tang B. Wang X. Li Q. et al, Estimation of the transmission risk of 2019-nCov and its implication for public health interventions. Electronic copy available at: https://ssrn.com/abstract $=3525558$.

16. $\mathrm{Wu}, \mathrm{JQ}$ and Zha, P. Treatment Strategies for Reducing Damages to Lungs in Coronavirus and Other Lung Infections (February 6, 2020). Available at SSRN: https://ssrn.com/abstract $=3533279$ or http://dx.doi.org/10.2139/ssrn.3533279

17. Wu, JQ and Zha, P. Preventive, Mitigating and Treatment Strategies for Containing or Ending the COVID-19 Pandemic (a first update) (February 25, 2020). Available at SSRN: https://ssrn.com/abstract $=3544428$ or http://dx.doi.org/10.2139/ssrn.3544428.

18. Wu, JQ and Zha, P. Association of COVID-19 Disease Severity with Transmission Routes and Suggested Changes to Community Guidelines (March 13, 2020). Available at SSRN: https://ssrn.com/abstract $=3554043$ or http://dx.doi.org/10.2139/ssrn.3554043.

19. Wu, JQ and Zha, P. Mask Is a Double-edged Sword in the Fight Against COVID-19 Pandemic (March 28, 2020). Available at SSRN: https://ssrn.com/abstract=3563851 or http://dx.doi.org/10.2139/ssrn.3563851

20. Ellis, Emory; Delbruck, Max. The Growth of Bacteriophage. The Journal of General Physiology. 1939, 22(3): 365-384.

21. Zwart MP, Hemerik L, Jenny S. et al. An experimental test of the independent action hypothesis in virus-insect pathosystems. Proc. R. Soc. B (2009) 276, 2233-2242.

22. Leeks A, Sanjuán R, and West SA. The evolution of collective infectious units in viruses. Virus Res. 2019 May; 265: 94-101.

23. Vignuzzi M., Stone J. K., Arnold J. J., et al. Quasispecies Diversity Determines Pathogenesis Through Cooperative Interactions in a Viral Population, Nature, 2006, 439: 344-8.

24. Shirogane Y, Watanabe S, Yanagi Y. Cooperation between different variants: A unique potential for virus evolution. Virus Res. 2019 Apr 15;264:6873.

25. Leeks A., Segredo-Otero E.A., Sanjuán R., West S.A. Beneficial coinfection can promote within-host viral diversity. Virus Evol. 2018;4/2.

26. Weibel ER. On the Tricks Alveolar Epithelial Cells Play to Make a Good Lung. Am J Respir Crit Care Med Vol 191, Iss 5, pp 504-513, Mar 1, 2015. 
27. Fabian P., McDevitt JJ, DeHaan WH. Influenza virus in human exhaled breath: an observational study. PLoS One 2008,3, e2691.

28. Stelzer-Braid S, Oliver BG, Blazey AJ, Argent E, Newsome TP, Rawlinson WD, Tovey ER. Exhalation of respiratory viruses by breathing, coughing, and talking. J Med Virol. 2009B;81:1674-1679.

29. Lindsley WG, Blachere FM, Thewlis RE, Vishnu A, Davis KA, Cao G, Palmer JE, Clark KE, Fisher MA, Khakoo R, Beezhold DH. Measurements of airborne influenza virus in aerosol particles from human coughs. PLoS ONE. 2010;5:e15100.

30. Milton DK, Fabian MP, Cowling BJ, Grantham ML, McDevitt JJ. Influenza virus aerosols in human exhaled breath: particle size, culturability, and effect of surgical masks. PLoS pathogens. 2013;9:e1003205.

31. Lindsley WG, Pearce TA, Hudnall JB, Davis KA, Davis SM, Fisher MA, Khakoo R, Palmer JE, Clark KE, Celik I, Coffey CC, Blachere FM, Beezhold DH. Quantity and size distribution of cough-generated aerosol particles produced by influenza patients during and after illness. J Occup Environ Hyg. 2012;9:443449.

32. Coleman KK., Sigler WV. Airborne Influenza A Virus Exposure in an Elementary School. Scientific Reports volume 10, Article number: 1859 (2020)

33. Alonso C, Goede DP, Morrison RB, Davies PR, Rovira A, Marthaler DG, Torremorell M. Evidence of infectivity of airborne porcine epidemic diarrhea virus and detection of airborne viral RNA at long distances from infected herds. Vet Res. 2014 Jul 14;45:73. doi: 10.1186/s13567-014-0073-z.

34. Alonso C, Raynor PC., Goyal S, Olson BA, Alba A, Davies PR, Torremorell M. Assessment of air sampling methods and size distribution of virus-laden aerosols in outbreaks in swine and poultry farms. Journal of Veterinary Diagnostic Investigation 2017, Vol. 29(3) 298-304.

35. Arruda AG, Tousignant S, Sanhueza J, Vilalta C, Poljak Z, Torremorell M, Alonso C, Corzo CA. Aerosol Detection and Transmission of Porcine Reproductive and Respiratory Syndrome Virus (PRRSV): What Is the Evidence, and What Are the Knowledge Gaps? Viruses. 2019 Aug 3; 11(8). Epub 2019 Aug 3.

36. Corzo CA, Culhane M, Dee S, Morrison RB, Torremorell M. Airborne Detection and Quantification of Swine Influenza A Virus in Air Samples Collected Inside, Outside and Downwind from Swine Barns. PLoS One. 2013 Aug 8;8(8):e71444. 
37. Alonso C, Raynor PC, Davies PR, Torremorell M. Concentration, Size Distribution, and Infectivity of Airborne Particles Carrying Swine Viruses. PLoS One. 2015 Aug 19;10(8):e0135675. doi: 10.1371/journal.pone.0135675. ECollection 2015.

38. Hall CB. Nosocomial viral respiratory infections: perennial weeds on pediatric wards. Am J Med. 1981;70:670-676.

39. Hall CB, Douglas RG, Jr, Geiman JM, Meagher MP. Viral shedding patterns of children with influenza B infection. J Infect Dis. 1979;140:610-613.

40. Frank AL, Taber LH, Wells CR, Wells JM, Glezen WP, Paredes A. Patterns of shedding of myxoviruses and paramyxoviruses in children. J Infect Dis. 1981;144:433-441.

41. Weinstock DM, Gubareva LV, Zuccotti G. Prolonged shedding of multidrug-resistant influenza A virus in an immunocompromised patient. N Engl J Med. 2003;348:867-868.

42. Sato M, Hosoya M, Kato K, Suzuki H. Viral shedding in children with influenza virus infections treated with neuraminidase inhibitors. Pediatr Infect Dis J. 2005;24:931-932.

43. Glezen WP. Influenza control. N Engl J Med. 2006;355:79-81.

44. Westphalen K, Gusarova GA, Islam MN, Subramanian M, Cohen TS, Prince AS, Bhattacharya J. Sessile alveolar macrophages communicate with alveolar epithelium to modulate immunity. Nature. 2014;506(7489):503-6.

45. Kirby AC, Coles MC, Kaye PM. Alveolar macrophages transport pathogens to lung draining lymph nodes. J Immunol. 2009;183(3):1983-9.

46. Bhattacharya J. and Westphalen K.Macrophage-epithelial interactions in pulmonary alveoli. Semin Immunopathol. 2016 Jul; 38(4): 461-469.

47. Rodero MP, Poupel L, Loyher P-L et al. Immune surveillance of the lung by migrating tissue monocytes. eLife 2015;4:e07847. DOI: 10.7554/eLife.07847

48. Coronavirus disease (COVID-19) advice for the public: When and how to use masks. https://www.who.int/emergencies/diseases/novel-coronavirus-2019/ advice-for-public/when-and-how-to-use-masks

49. CDC. How to Protect Yourself, Accessed at https://www.cdc.gov/coronavirus/2019-ncov/prevent-getting-sick/prevention.html Last Access on March 28, 2020.

50. Qualls N, Levitt A, Kanade N. et al. Community Mitigation Guidelines to Prevent Pandemic Influenza - United States, 2017. Carrie Reed MMWR 
Recomm Rep. 2017 Apr 21; 66(1): 1-32. Published online 2017 Apr 21. doi: 10.15585/mmwr.rr6601a1. 